\title{
A nature-inspired conjugated polymer for high performance transistors and solar cells
}

Kealan J. Fallon ${ }^{\dagger}$, Nilushi Wijeyasinghe ${ }^{\dagger}$, Nir Yaacobi-Gross ${ }^{+}$, Raja S. Ashraf $f^{\dagger}$ David Freeman ${ }^{\dagger}$, Robert G. Palgrave ${ }^{\dagger}$, Mohammed Al-Hashimill, Tobin J. Marks ${ }^{\S}$, Iain McCulloch ${ }^{*}$, Thomas D. Anthopoulos ${ }^{\dagger}$ and Hugo Bronstein ${ }^{\dagger *}$

†Department of Chemistry, Christopher Ingold Building, University College London, London WC1H 0AJ, U.K.

Centre for Plastic Electronics, Imperial College London, London, SW7 2AZ, UK

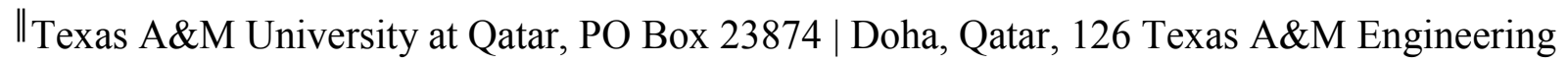
Building | Education City

${ }^{\S}$ Department of Chemistry, the Materials Research Center, and the Argonne-Northwestern Solar Energy Research Center, Northwestern University, 2145 Sheridan Road, Evanston, Illinois 60208, USA

\begin{abstract}
A novel, highly soluble chromophore for use in organic electronics based on an indigoid structure is reported. Co-polymerization with thiophene affords an extremely narrow band-gap polymer with a maximum absorption at $\sim 800 \mathrm{~nm}$. The novel polymer exhibits high crystallinity, and high,
\end{abstract}


ambipolar transport in OFET devices of $\sim 0.23 \mathrm{~cm}^{2} \mathrm{~V}^{-1} \mathrm{~s}^{-1}$ for holes and $0.48 \mathrm{~cm}^{2} \mathrm{~V}^{-1} \mathrm{~s}^{-1}$ for electrons. OPV device efficiencies up to $2.35 \%$ with light absorbance up to $950 \mathrm{~nm}$, demonstrating potential for this novel chromophore in near-IR photovoltaics.

\section{Introduction}

The development of novel organic conjugated polymers has gained momentum in recent times due to their possible applications in organic photovoltaic (OPV) and organic field-effect transistor (OFET) devices where their lower cost, light weight, and mechanical flexibility are all attractive properties. Current high performance polymers have enabled OFET devices with mobilities in excess of $2 \mathrm{~cm}^{2} \mathrm{~V}^{-1} \mathrm{~s}^{-1}$, and OPV devices with power conversion efficiencies (PCEs) of over 8\%. ${ }^{1-}$

${ }^{3}$ Ultra-narrow band gap conjugated polymers are of great interest due to the ease of charge injection when incorporated into ambipolar OFETs, and also their near-IR optical absorption for use in both tandem and transparent OPV devices. ${ }^{4}$ Considerable interest has focused on planar bislactam containing polymers such as diketopyrrolopyrrole (DPP) $\mathbf{1}^{5}$ and isoindigo $\mathbf{2}^{6}$. The electron withdrawing nature of the lactam core alongside its planarity has enabled DPP and isoindigo containing conjugated polymers to reach both OPV PCEs and OFET mobilities. 
<smiles>O=C1NC(c2cccs2)=C2C(=O)NC(c3cccs3)=C12</smiles>

1<smiles>O=C1/C(=C2\Nc3ccccc3C2=O)Nc2ccccc21</smiles>

3<smiles>O=C1Nc2ccccc2/C1=C1/C(=O)Nc2ccccc21</smiles>

2<smiles>[R]C1=c2c3ccccc3n3c(=O)c([R])c4c(c5ccccc5n4C1=O)c23</smiles>

IND

$$
\mathrm{R}=\mathrm{Ph}, \text { INDP }
$$

Figure 1. Bis-lactam containing compounds and polymer building blocks

Indigo 3 is the most produced natural dye worldwide, and has a highly planar structure arising from intramolecular hydrogen bonding between the oxygen and the amide protons of the indol-3one units. ${ }^{7}$ Upon photoexcitation, rotation about the central carbon-carbon bond can effect transcis isomerisation ${ }^{8}$ as well as either single or double proton transfer, resulting in rapid energy loss through internal conversion, thereby negating any potential for OPV devices. ${ }^{9}$ As a semiconductor in OFET devices, indigo has shown hole mobilities up to $1 \times 10^{-2} \mathrm{~cm}^{2} \mathrm{~V}^{-1} \mathrm{~s}^{-1} .{ }^{10}$ More recently, functionalised indigoids have been investigated, and the mobility can be slightly enhanced to $1.3 \times 10^{-2} \mathrm{~cm}^{2} \mathrm{~V}^{-1} \mathrm{~s}^{-1}$ using 5,5'-dichloroindigo. ${ }^{11}$ Crucially the use of naturally occurring compounds as building blocks for materials in organic electronics can begin to address the issues of sustainability associated with them. As an example, Cibalackrot (7,14-diphenyldiindolo[3,2,1de:3',2',1'-ij][1,5]naphthyridine-6,13-dione, INDP) is an indigo derivative first synthesised in 1914 
by condensation of indigo and phenylacetyl chloride. ${ }^{12}$ Importantly, the molecule is locked in a highly planar rigid conformation where proton transfer and trans-cis isomerization are not possible. This highly conjugated compound has similar functionality to compounds containing the popular bis-lactam system, and hence polymers based on this structure display interesting electronic properties. Remarkably however, there are almost no reports of IND implementation in organic electronics. Glowacki et al. reported the use of the parent small molecule in OFET devices to obtain reasonable OFET mobilities, ${ }^{13}$ and very recently He et al. demonstrated its use as a comonomer to achieve high field effect mobilities when co-polymerized with solubilizing comonomers. ${ }^{14}$ We were interested in developing soluble IND derivatives which would not require co-polymerization with complex co-monomers, and here we report the first synthesis of such materials and their potential for use in organic electronics. By demonstrating the use of conjugated polymers containing natural occurring and potentially bio-sustainable building blocks we believe that we are taking important steps towards addressing the issue of sustainability in organic electronics.

\section{Results and Discussion}

The synthesis (Scheme 1) begins with protection of commercially available 5-hydroxy-2nitrobenzaldehyde 4 with 3,4-dihydro-2H-pyran, followed by an aldol condensation to give $(E)$ 5,5'-bis((tetrahydro-2H-pyran-2-yl)oxy)-[2,2'-biindolinylidene]-3,3'-dione $\quad 6 . \quad$ A subsequent condensation reaction and concurrent deprotection of the tetrahydropyranyl groups affords the 2,9dihydroxy-7,14-di(thiophen-2-yl)diindolo[3,2,1-de:3',2',1'-ij][1,5]naphthyridine-6,13-dione 
(INDT) compound $\mathbf{8}$. This compound was then alkylated with 2-octyldodecyl chains to improve solubility and then subsequently brominated with N-bromosuccinimide to afford our new novel INDT monomer 9. Co-polymerization via Stille coupling of monomer 9 with simple bistrimethylstannylthiophene affords polymer INDT-T which was purified by Soxhlet extraction using acetone, then hexane, to remove low molecular weight oligomers, and finally chloroform. The dark green polymeric product is soluble in common organic solvents such as chloroform and chlorobenzene.

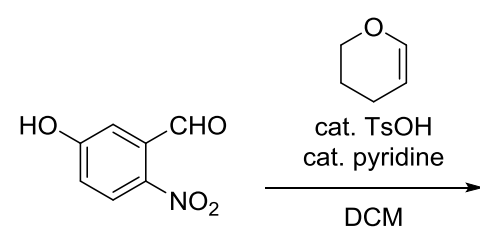

4

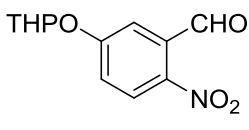

5

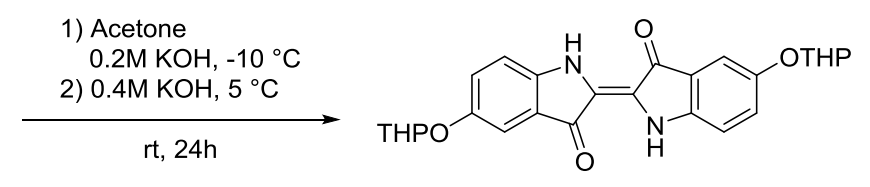

6

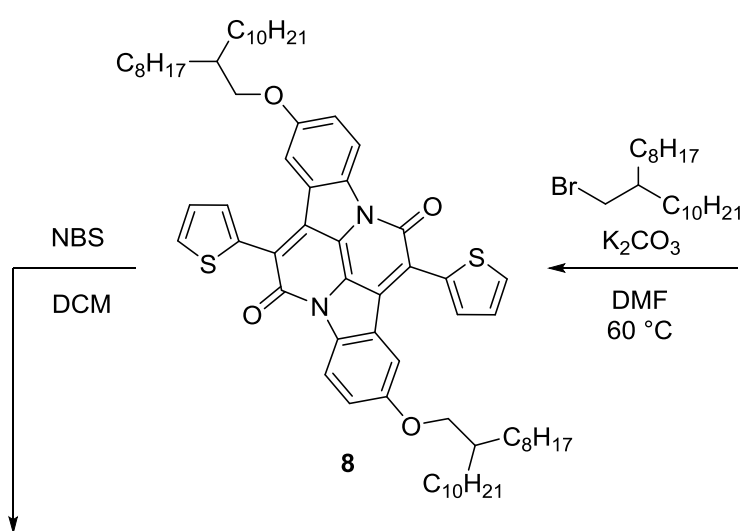<smiles></smiles>

1.<smiles>O=C(Cl)Cc1cccs1</smiles>
xylene, reflux

2. $5 \% \mathrm{NaOH}$ $\mathrm{MeOH}$

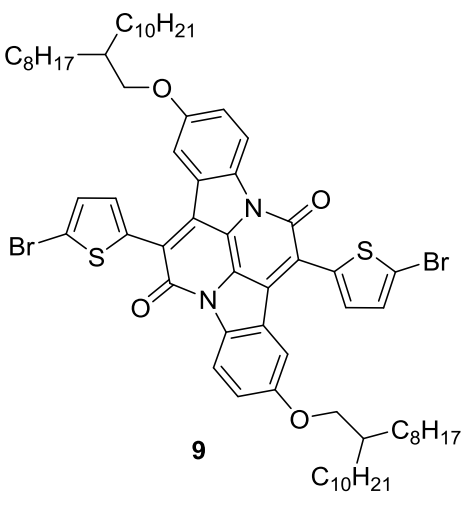
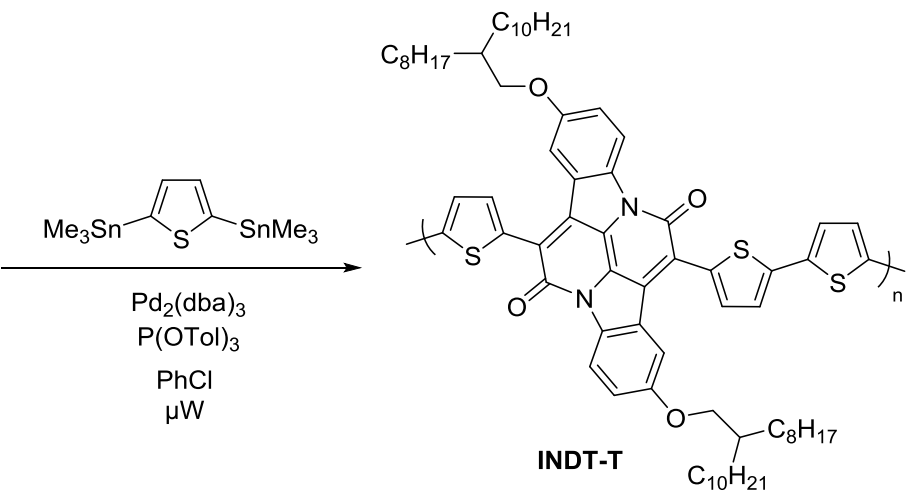

Scheme 1. Synthetic route to the novel INDT monomer 


\begin{tabular}{|c|c|c|c|c|c|c|c|c|}
\hline $\mathrm{Mn}^{\mathrm{a}}$ & $\mathrm{Mw}^{\mathrm{a}}$ & $\mathrm{PDI}^{\mathrm{a}}$ & $\begin{array}{l}\lambda_{\max }{ }^{\text {soln }} \\
(\mathrm{nm})^{\mathrm{b}}\end{array}$ & $\begin{array}{l}\lambda_{\max }{ }^{\text {film }} \\
(\mathrm{nm})^{\mathrm{c}}\end{array}$ & $\begin{array}{l}\text { HOMO } \\
(\mathrm{eV})^{\mathrm{d}}\end{array}$ & $\begin{array}{l}\text { LUMO } \\
(\mathrm{eV})^{\mathrm{e}}\end{array}$ & $\mathrm{E}_{\mathrm{g}}(\mathrm{eV})^{\mathrm{c}}$ & $\begin{array}{l}E_{g}{ }^{\text {calc }} \\
(e V)^{f}\end{array}$ \\
\hline 15,700 & 49,400 & 3.15 & 797 & 790 & -4.24 & -3.02 & 1.22 & 1.32 \\
\hline
\end{tabular}

Table 1. Physical and Optical Properties of INDT-T

a) determined by $\mathrm{SEC}(\mathrm{PS})$ using $\mathrm{PhCl}$ as eluent b) $\mathrm{PhCl}$ solution c) spin-coated from $\mathrm{PhCl}$ $5 \mathrm{mg} / \mathrm{mL} \mathrm{d}$ ) determined by XPS e) HOMO + optical energy gap f) determined by TD-DFT using B3LYP/6-31g*

The molecular mass of INDT-T was determined by SEC(PS) to be Mn $15.7 \mathrm{KDa}$ and $\mathrm{Mw}$ 49.4 KDa which, although is perhaps lower than optimal, is sufficient to evaluate the promise of this material in organic electronic devices. Figure 2 a shows the solution (chlorobenzene) and thin film (spin coated from a $5 \mathrm{mg} / \mathrm{mL}$ solution in chlorobenzene) UV-Vis absorption spectra of INDTT. Both spectra show a broad featureless absorption in the near-IR with $\lambda_{\max } \sim 790 \mathrm{~nm}$. The spectrum becomes somewhat broadened on going from solution to thin films which is attributed to solid state packing effects, often observed in similar materials. The optical band gap in the film can be estimated to be $\sim 1.22 \mathrm{eV}$, demonstrating the effectiveness of the IND core at creating nearIR absorbing materials. The HOMO and LUMO energy levels were determined by XPS and the optical energy gap and are found to be $-4.24 \mathrm{eV}$ and $-3.02 \mathrm{eV}$, respectively. Both values are in a similar range to typical DPP and isoindigo polymers, thus showing that the IND containing polymers are an important addition to the bis-lactam containing conjugated polymer family. 


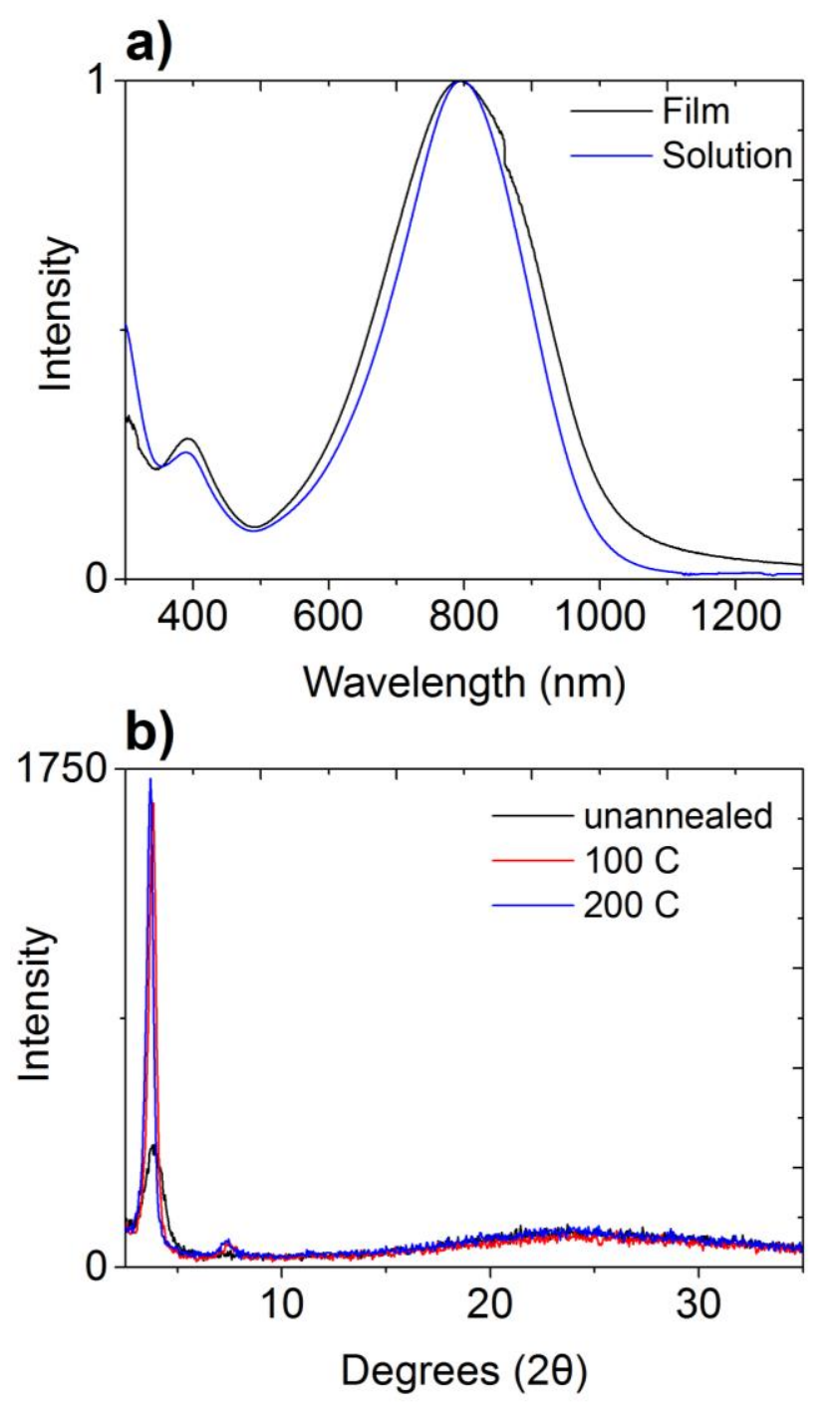

Figure 2. a) Normalised UV-vis absorption spectra of INDT-T. Solution spectra was recorded in chlorobenzene and thin-film were spun from a $5 \mathrm{mg} / \mathrm{mL}$ solution of INDT-T in chlorobenzene b) X-ray diffraction of a drop-cast INDT-T film from a $5 \mathrm{mg} / \mathrm{mL}$ solution of INDT-T in chlorobenzene

The influence of annealing temperature on the molecular packing in INDT-T thin films was studied by X-ray diffraction (Figure $2 \mathrm{~b})$. Drop-cast polymer thin films $(5 \mathrm{mg} / \mathrm{mL}$ solution in chlorobenzene) shows a Bragg reflection at $2 \theta=3.8^{\circ}$, corresponding to the (100) reflection and indicative of a typical lamellar packing distance of $2.3 \mathrm{~nm}$. Annealing at $100{ }^{\circ} \mathrm{C}$ for $10 \mathrm{~min}$ leads 
to a substantial increase in thin film crystallinity as observed by the increased intensity of the (100) peak, though we note that this improvement may not necessarily arise from increased ordering of the $\pi-\pi$ stacking in the thin film. ${ }^{15}$ The appearance of the corresponding (200) reflection also indicates increased long range order. No noticeable changes in the in the film crystallinity are observed after annealing at higher temperatures.

To investigate the electronic structure of the new polymer, DFT calculations were carried out on model trimers with methoxy substituents. The calculated energy gap is found to be $1.32 \mathrm{eV}$, in good agreement with experiment. Figure 3 shows the HOMO and LUMO distributions of the geometry optimized structure of INDT-T using Gaussian 09 (DFT, B3LYP/6-31G*). The backbone displays a high degree of co-planarity indicating that charge transport in this materials should be efficient. Both the HOMO and LUMO are delocalized well over both the thiophenes and the central bis-lactam core. However, while there is little contribution to the HOMO from the peripheral phenyl groups, there is substantial delocalisation of the LUMO onto these sites. This indicates that further substitutions at these positions will enable independent manipulation of the LUMO level without disruption of the HOMO. 

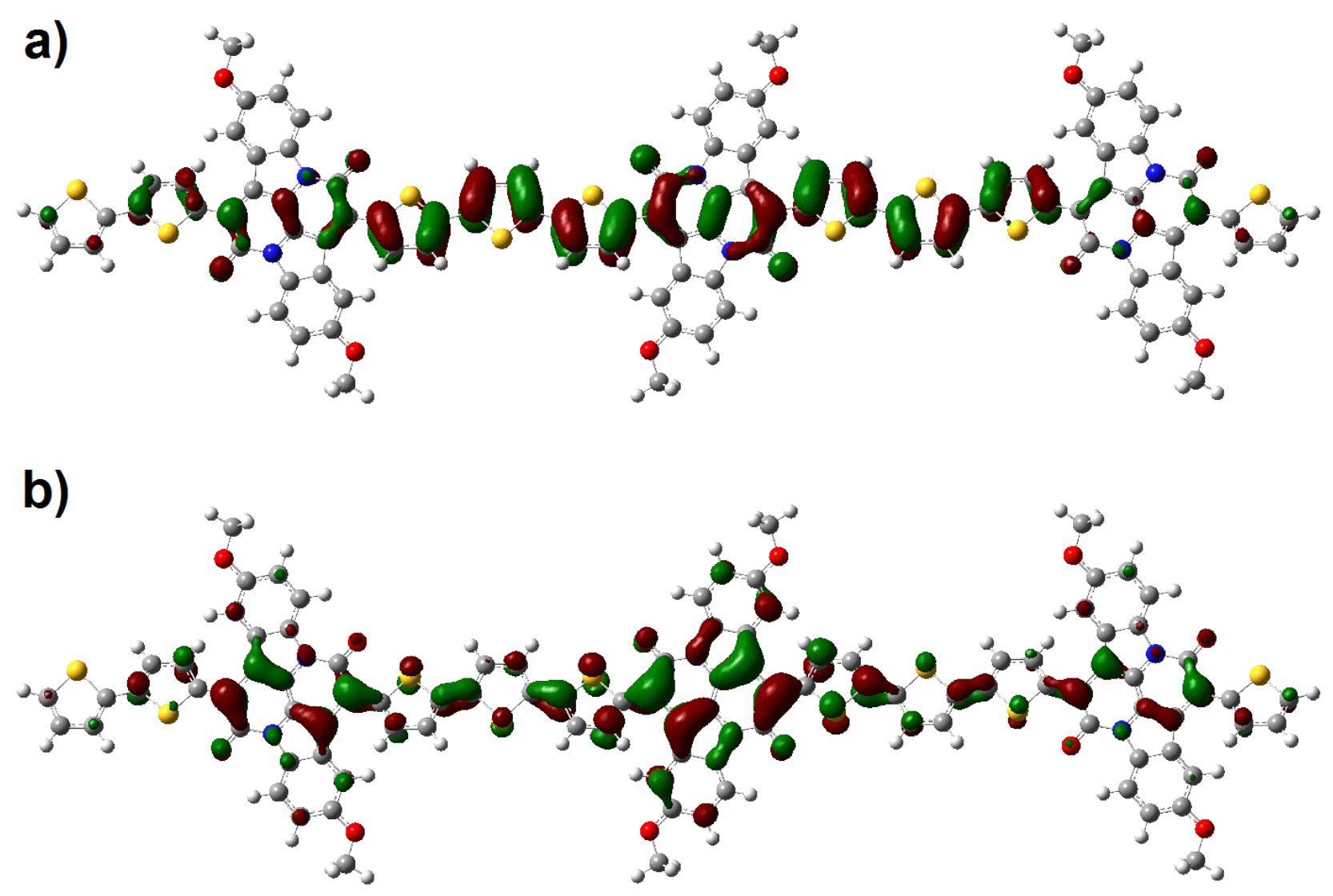

Figure 3. The a) HOMO and b) LUMO distributions of the geometry optimized structure of INDT-T using Gaussian 09 (DFT, B3LYP/6-31G*)

OFETs with Top Gate-Bottom Contact architecture were fabricated using the novel polymer on glass substrates with CYTOP dielectric. Al + Au bilayer $(20 \mathrm{~nm}+20 \mathrm{~nm})$ electrodes for ambipolar charge transport were used. The organic semiconductor layer was spin-coated on top of the substrates from a chlorobenzene solution $(10 \mathrm{mg} / \mathrm{mL})$. Finally, CYTOP dielectric was spincoated on top followed by a thermally evaporated Al gate electrode. Representative transfer and output characteristics are shown in Figure 4, and data are compiled in Table 2 and 3 . The $100{ }^{\circ} \mathrm{C}$ annealed film maximum hole and electron mobilities extracted extracted from the saturation regime of the transfer curves were both approximately $0.08 \mathrm{~cm}^{2} \mathrm{~V}^{-1} \mathrm{~s}^{-1}$ demonstrating good balanced ambipolar 
behaviour and negligible hysteresis. Annealing the devices at $200{ }^{\circ} \mathrm{C}$ leads to significant improvement in both the hole and electron mobility. A high hole mobility of $0.23 \mathrm{~cm}^{2} \mathrm{~V}^{-1} \mathrm{~s}^{-1}$ for was determined from the best fit of the second derivative of transfer curve saturation regime with the peak value measured being $0.52 \mathrm{~cm}^{2} \mathrm{~V}^{-1} \mathrm{~s}^{-1}$. The best-fit value for the electron mobility was $0.48 \mathrm{~cm}^{2} \mathrm{~V}^{-1} \mathrm{~s}^{-1}$ with a remarkable peak mobility of $1.2 \mathrm{~cm}^{2} \mathrm{~V}^{-1} \mathrm{~s}^{-1}$, however we note that there was a significant amount of noise present in the second derivative mobility extraction plot. As was shown in XRD experiments, we believe that the improved OFET characteristics are due to the increased ordering of the INDT-T polymer with annealing.

\begin{tabular}{|c|c|c|c|c|c|c|c|}
\hline $\begin{array}{c}\text { Annealing } \\
\text { Temp. } \\
/{ }^{\circ} \mathrm{C}\end{array}$ & $\begin{array}{l}\text { Channel } \\
\text { Length } \\
/ \mu \mathrm{m}\end{array}$ & $\begin{array}{c}\mu_{\text {hole }}{ }^{\mathrm{a}, \mathrm{b}} \\
\text { (peak value) } \\
/ \mathrm{cm}^{2} \mathrm{~V}^{-1} \mathrm{~s}^{-1}\end{array}$ & $\begin{array}{c}\mathrm{V}_{\text {th,,hole }}^{\mathrm{c}} \\
/ \mathrm{V}\end{array}$ & $\begin{array}{l}\mathrm{I}_{\text {on }} / \mathrm{I}_{\text {off }} \\
\text { for } \\
\text { holes }\end{array}$ & $\begin{array}{c}\mu_{\text {electron }}{ }^{\mathrm{a}, \mathrm{b}} \\
\text { (peak value) } \\
/ \mathrm{cm}^{2} \mathrm{~V}^{-1} \mathrm{~s}^{-1}\end{array}$ & $\begin{array}{c}\mathrm{V}_{\text {th,electro }}{ }^{\mathrm{c}} \\
/ \mathrm{V}\end{array}$ & $\begin{array}{l}\mathrm{I}_{\mathrm{on}} / \mathrm{I}_{\mathrm{off}} \\
\text { for } \\
\text { electro } \\
\mathrm{ns}^{\mathrm{c}}\end{array}$ \\
\hline \multirow[t]{3}{*}{100} & 40 & $\begin{array}{c}0.04 \pm 0.003^{\mathrm{d}} \\
(0.046 \pm 0.002)\end{array}$ & $-120 \pm 8$ & $10^{4}$ & $\begin{array}{l}0.075 \pm 0.01 \\
(0.11 \pm 0.03)\end{array}$ & $43 \pm 5$ & $10^{5}$ \\
\hline & 50 & $\begin{array}{l}0.076 \\
(0.09)\end{array}$ & -23 & $10^{5}$ & $\begin{array}{c}0.075 \\
(0.094)\end{array}$ & 22 & $10^{6}$ \\
\hline & 100 & $\begin{array}{l}0.048 \\
(0.069)\end{array}$ & -90 & $10^{5}$ & $\begin{array}{l}0.079 \\
(0.13)\end{array}$ & 29 & $10^{6}$ \\
\hline 200 & 50 & $\begin{array}{l}0.23 \pm 0.1^{\mathrm{e}} \\
(0.52 \pm 0.08)\end{array}$ & $-131 \pm 2$ & $10^{3}$ & $\begin{array}{c}0.48 \pm 0 \\
(1.2 \pm 0.05)\end{array}$ & $52 \pm 3$ & $10^{6}$ \\
\hline
\end{tabular}

${ }^{a} \mu_{\text {hole }}$ and $\mu_{\text {electron }}$ refer to the highest effective mobilities measured in the saturation regime for a gate-voltage range of $20 \mathrm{~V}$. ${ }^{b}$ Peak values for saturation regime mobility are given in brackets next to the best-fit values because the second derivative plots are noisier. ${ }^{\mathrm{c}} \mathrm{The}$ threshold voltages $\left(\mathrm{V}_{\text {th }}\right)$ and the on-to-off ratios $\left(\mathrm{I}_{\mathrm{on}} / \mathrm{I}_{\text {off }}\right)$ were extracted from the linear regime $\left(\mathrm{V}_{\mathrm{d}}=-30 \mathrm{~V}\right.$ (all devices) except for $200{ }^{\circ} \mathrm{C}$ annealed (-90V) for holes and $\mathrm{V}_{\mathrm{d}}=30 \mathrm{~V}$ (all devices) except for $40 \mu \mathrm{m}$ device $(60 \mathrm{~V})$ for electrons). ${ }^{\mathrm{d} A v e r a g e}$ of 4 devices. ${ }^{\mathrm{e}}$ Average of 2 devices

Table 2. OFET Characteristics of INDT-T 

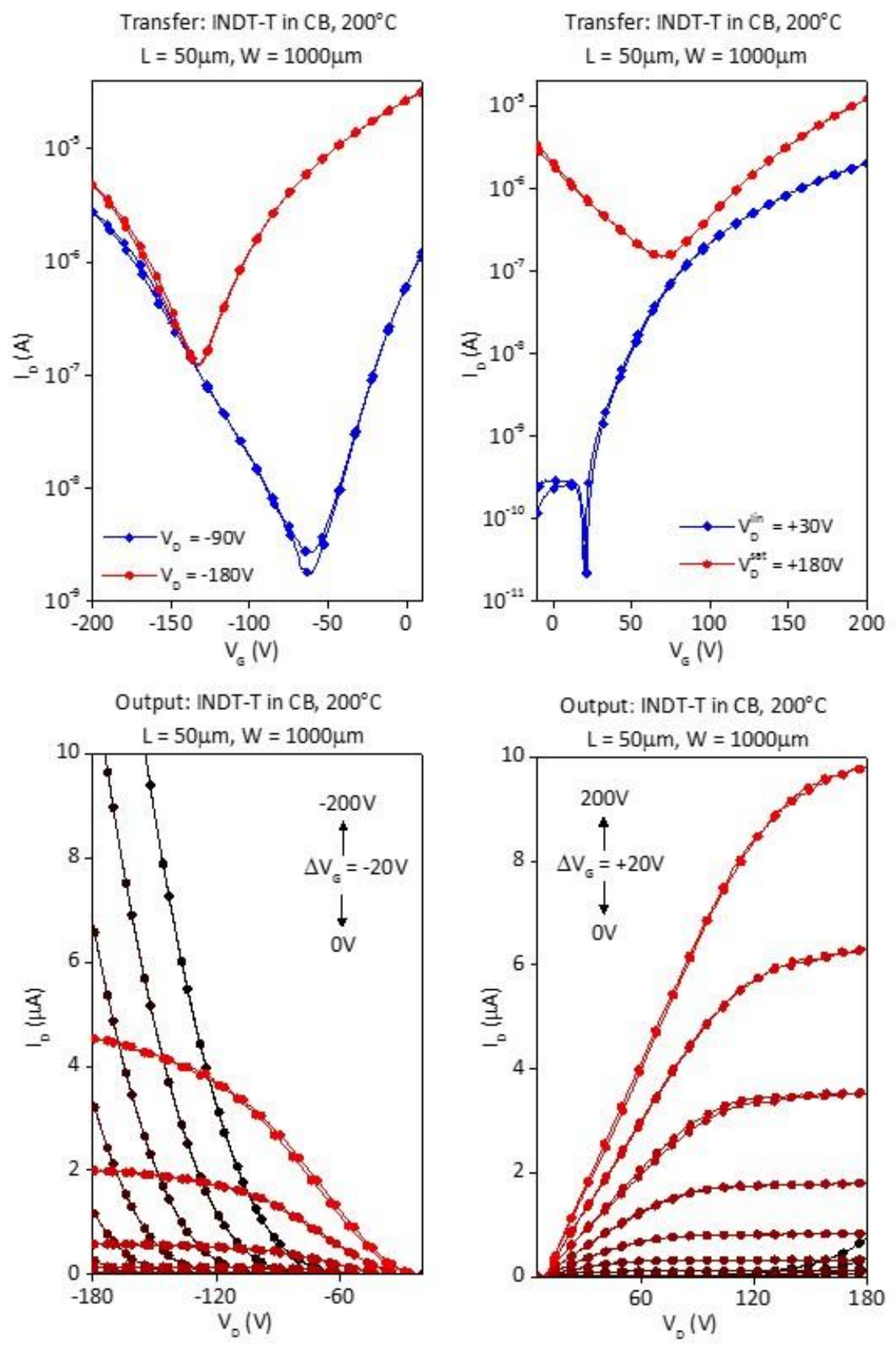

Figure 4. The transfer and output characteristics of an OFET devices of INDT-T annealed at $200^{\circ} \mathrm{C}$

The threshold voltage for electrons was in the range of $\sim 20-50 \mathrm{~V}$ which are comparable to values measured in DPP and iso-indigo based OFETs. However the large threshold voltages for holes 
indicates an injection barrier for holes. We attribute this to non-optimized matching of the electrodes and the polymer HOMO. To overcome this OFETs with $\mathrm{UV}-\mathrm{O}_{3}$ treated Au electrodes with an $\mathrm{Al}$ adhesion layer $(40 \mathrm{~nm}+5 \mathrm{~nm})$ for optimized hole injection due to a deeper work function were fabricated. The results are shown in Table 3.

\begin{tabular}{|c|c|c|c|c|}
\hline $\begin{array}{c}\text { Annealing } \\
\text { Temp. } \\
/{ }^{\circ} \mathrm{C}\end{array}$ & $\begin{array}{c}\text { Channel } \\
\text { Length } \\
/ \mu \mathrm{m}\end{array}$ & $\begin{array}{c}\mu_{\text {hole }}^{\mathrm{a}, \mathrm{b}} \\
\text { (peak value) } \\
/ \mathrm{cm}^{2} \mathrm{~V}^{-1} \mathrm{~s}^{-1}\end{array}$ & $\begin{array}{c}\mathrm{V}_{\text {th,hole }}^{\mathrm{c}} \\
/ \mathrm{V}\end{array}$ & $\begin{array}{c}\mathrm{I}_{\mathrm{on}} / \mathrm{I}_{\text {off }} \\
\text { for } \\
\text { holes }^{\mathrm{c}}\end{array}$ \\
\hline 100 & 30 & $\begin{array}{c}0.1 \pm 0.01^{\mathrm{d}} \\
(0.13 \pm 0.015)\end{array}$ & $-14 \pm 0.5$ & $10^{4}$ \\
\hline
\end{tabular}

${ }^{a} \mu_{\text {hole }}$ refers to the highest effective mobilities measured in the saturation regime for a gate-

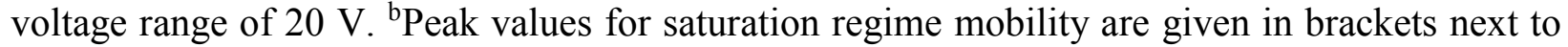
the best-fit values because the second derivative plots are noisier. ${ }^{c}$ The threshold voltages $\left(\mathrm{V}_{\text {th }}\right)$ and the on-to-off ratios $\left(\mathrm{I}_{\mathrm{on}} / \mathrm{I}_{\mathrm{off}}\right)$ were extracted from the linear regime $\left(\mathrm{V}_{\mathrm{d}}=-30 \mathrm{~V}\right)$ for holes. ${ }^{\mathrm{d}}$ Average of 2 devices

Table 3. Hole optimized OFET Characteristics of INDT-T

Only p-type transport was observed for these devices, however it is clear that both the measured hole mobility and threshold voltage are significantly improved relative to the equivalent devices presented in Table 2. This indicates that the larger threshold voltages observed in the initial device data is likely due to improper work function matching, or sub-optimal metal-polymer contact. Bottom gate-Bottom contact OFET devices were also fabricated but these suffered from significant hysteresis and lower mobilities.

Conventional and inverted bulk-heterojunction OPV devices were fabricated using a 1:2 blend of INDT-T:PC ${ }_{71} \mathrm{BM}$ as the active layer spin-coated from a 4:1 $\mathrm{CHCl}_{3}: \mathrm{ODCB}$ solution $(10 \mathrm{mg} / \mathrm{mL})$. The J-V curves and EQE are shown in Figure 5 and the data is presented in Table 4. The conventional OPV device provides a PCE of $2.25 \%$, with a short circuit current $\left(\mathrm{J}_{\mathrm{sc}}\right)$ of $6.27 \mathrm{~mA}$ 
$\mathrm{cm}^{-2}$, an open circuit voltage $\left(\mathrm{V}_{\mathrm{oc}}\right)$ of $0.62 \mathrm{~V}$, and a fill factor $(\mathrm{FF})$ of 0.58 . The relatively high open circuit voltage is impressive considering the extremely narrow bandgap of INDT-T, and the devices all have relatively good fill factors, indicating good charge extraction at low fields. The inverted devices showed similar overall efficiencies of $2.35 \%$, but had slightly increased short circuit currents $\left(\mathrm{J}_{\mathrm{sc}}=6.88 \mathrm{~mA} \mathrm{~cm}{ }^{-2}\right)$ and lower open circuit voltages $\left(\mathrm{V}_{\mathrm{oc}}=0.59 \mathrm{~V}\right)$. Similar variations between conventional and inverted OPV devices have been shown before in DPP-based conjugated polymers. The EQE shows that the majority of the photocurrent originates from the fullerene absorption but there remains an appreciable contribution from the extremely near-IR absorbing INDT-T polymer up to $950 \mathrm{~nm}$. Despite the modest overall efficiencies, these devices represent some of the highest efficiencies from such ultra-narrow band-gap materials. ${ }^{16} \mathrm{We}$ believe that the lower contribution to the photocurrent is predominantly due to insufficient energetic offset of the polymer with respect to the fullerene. ${ }^{17}$ More importantly we demonstrate the first functioning OPV devices of this very novel chromophore indicating that it is well-suited for further development in this field. 

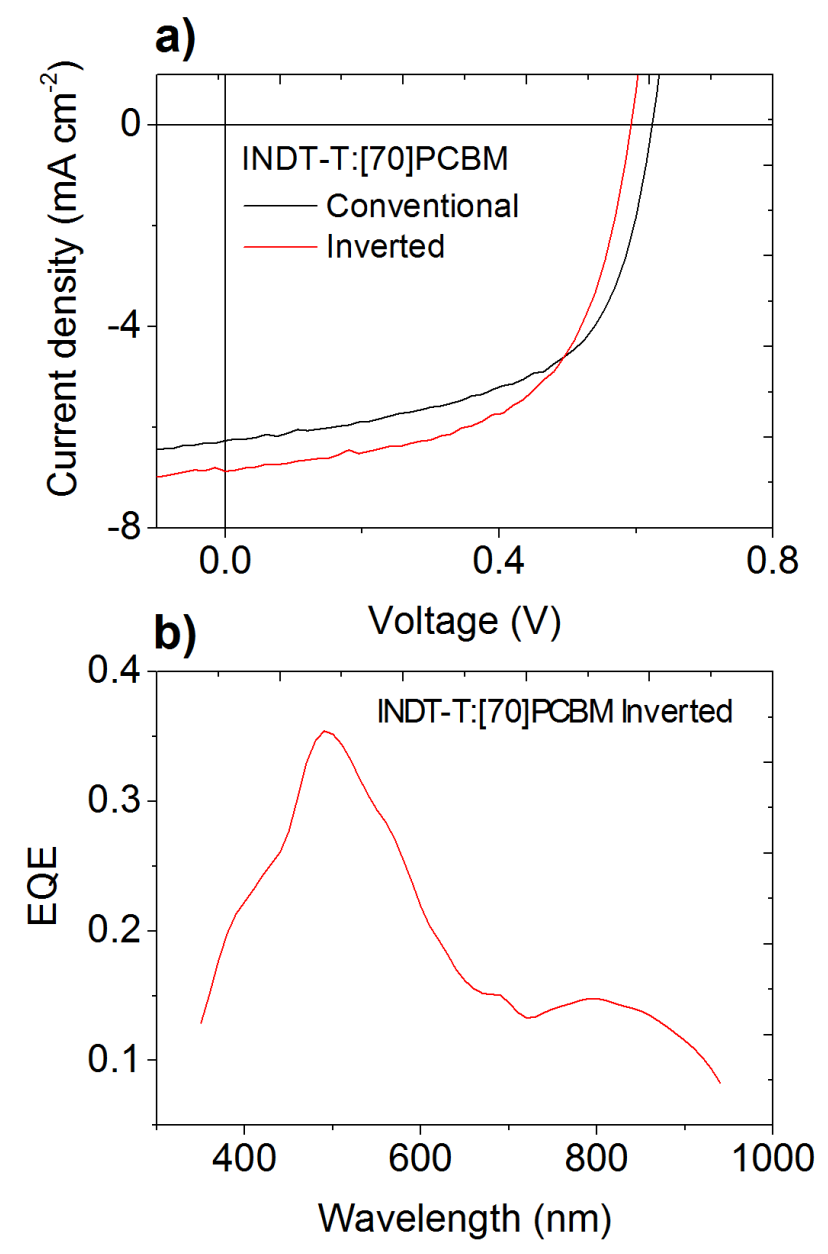

Figure 5. a) J-V characteristics of INDT-T:PC[70]BM solar cells b) External quantum efficiency of the INDT-T:PC[70]BM solar cell

\begin{tabular}{|l|l|l|l|l|}
\hline Architecture & $\mathrm{J}_{\mathrm{sc}}\left(\mathrm{mA} \mathrm{cm}^{-2}\right)$ & $\mathrm{V}_{\mathrm{oc}}(\mathrm{V})$ & FF & PCE (\%) \\
\hline Conventional & 6.27 & 0.62 & 0.58 & 2.25 \\
\hline Inverted & 6.88 & 0.59 & 0.58 & 2.35 \\
\hline
\end{tabular}

Table 4. OPV Device Characteristics of INDT-T-Based Solar Cells

\section{Conclusion}

We report the synthesis of a novel soluble monomer INDT for use in conjugated polymers based on naturally occurring indigo. Incorporation of this novel unit in a conjugated polymer, INDT-T, 
results in an extremely narrow band-gap material with high crystallinity. This polymer exhibits high ambipolar transport in OFET devices, with holes and electrons exhibiting mobilities of 0.23 $\mathrm{cm}^{2} \mathrm{~V}^{-1} \mathrm{~s}^{-1}$ and $0.48 \mathrm{~cm}^{2} \mathrm{~V}^{-1} \mathrm{~s}^{-1}$ respectively. Conventional and inverted OPV devices give efficiencies of up to $2.35 \%$ with photocurrent generated up to $950 \mathrm{~nm}$, demonstrating the potential of this novel monomer unit for implementation in near-IR OPV devices.

\section{Experimental Section}

\section{Characterisation}

${ }^{1} \mathrm{H}$ NMR spectra were recorded at $400 \mathrm{MHz}$ on a Bruker Avance 400 spectrometer, at $500 \mathrm{MHz}$ on a Bruker Avance 500 spectrometer, or at $600 \mathrm{MHz}$ on a Bruker Avance 600 spectrometer in the stated solvent using residual protic solvent $\mathrm{CHCl} 3(\delta=7.26 \mathrm{ppm}, \mathrm{s})$ or $\mathrm{DMSO}(\delta=2.56 \mathrm{ppm}$, qn $)$ as the internal standard. ${ }^{13} \mathrm{C}$ NMR spectra were recorded at $125 \mathrm{MHz}$ on a Bruker Avance 500 spectrometer or at $150 \mathrm{MHz}$ on a Bruker Avance 600 spectrometer in the stated solvent using the central reference of $\mathrm{CHCl} 3(\delta=77.0 \mathrm{ppm}, \mathrm{t})$ or $\mathrm{DMSO}(\delta=39.52 \mathrm{ppm}$, septet $)$ as the internal standard. Mass spectra were obtained using either a VG70-SE or MAT 900XP spectrometer at the Department of Chemistry, University College London. X-ray diffraction (XRD) measurements were carried out with a Bruker D4 Endeavour diffractometer equipped with a nickel-filtered $\mathrm{Cu}$ $\mathrm{K} \alpha 1$ beam and a scintillation counter detector and post-sample graphite monochromator, using a current of $30 \mathrm{~mA}$ and an accelerating voltage of $40 \mathrm{kV}$. UV-vis spectra were recorded on a Perkin-Elmer Lambda 950 spectrophotometer.

\section{Synthesis}

\section{2-nitro-5-((tetrahydro-2H-pyran-2-yl)oxy)benzaldehyde}

5-hydroxy-2-nitrobenzaldehyde (5.09 g, $31 \mathrm{mmol})$ and 3,4-dihydro-2H-pyran $(13.7 \mathrm{~mL}, 0.15$ mol) were dissolved in a 4:1 solution of dichloromethane:hexane $(61 \mathrm{~mL})$. p-Toluenesulfonic acid 
(58 $\mathrm{mg}, 1 \mathrm{~mol} \%)$ was suspended in dichloromethane $(15 \mathrm{~mL})$ and a few drops of pyridine were added. The acidic mixture was then added in one portion and the reaction stirred for $12 \mathrm{~h}$. Solvent and unreacted 3,4-dihydro-2H-pyran were then removed in vacuo to give a brown oil which was purified by flash chromatography on silica gel $\left(4: 1\right.$, PET:EtOAc, $\left.R_{F}=0.3\right)$ to give the product as a yellow oil (7.66 g, 100\%). ${ }^{1} \mathbf{H}$ NMR $\left(400 \mathrm{MHz}, \mathrm{CDCl}_{3}\right) \delta 10.49(\mathrm{~s}, 1 \mathrm{H}), 8.17(\mathrm{~d}, J=9.0 \mathrm{~Hz}, 1 \mathrm{H})$, $7.51(\mathrm{~d}, J=2.8 \mathrm{~Hz}, 1 \mathrm{H}), 7.33(\mathrm{dd}, J=9.0,2.8 \mathrm{~Hz}, 1 \mathrm{H}), 5.62(\mathrm{t}, J=2.8 \mathrm{~Hz}, 1 \mathrm{H}), 3.84-3.74(\mathrm{~m}$, 1H), $3.71-3.63(\mathrm{~m}, 1 \mathrm{H}), 1.96-1.90(\mathrm{~m}, 2 \mathrm{H}), 1.80-1.69(\mathrm{~m}, 2 \mathrm{H}), 1.68-1.62(\mathrm{~m}, 2 \mathrm{H})$ LRMS $(\mathrm{CI}+) m / z 252[\mathrm{MH}]^{+}$

\section{(E)-5,5'-bis(benzyloxy)-[2,2'-biindolinylidene]-3,3'-dione}

2-nitro-5-((tetrahydro-2H-pyran-2-yl)oxy)benzaldehyde ( $2.3 \mathrm{~g})$ was dissolved in acetone (34.5 $\mathrm{mL}$ ) and cooled to $-10{ }^{\circ} \mathrm{C}$. With vigorous stirring, a $0.2 \mathrm{M}$ solution of potassium hydroxide (4.6 $\mathrm{mL}$ ) was added dropwise over $15 \mathrm{~min}$, turning the solution pale yellow. After 30 min the solution was warmed to $5{ }^{\circ} \mathrm{C}$ and a $0.4 \mathrm{M}$ solution of potassium hydroxide $(34.5 \mathrm{~mL})$ was added dropwise, slowly. When half of this solution was added the reaction turned deep green, once addition was complete the reaction was a dark green/blue colour. After addition the reaction was covered and allowed to warm to room temperature and stir for $24 \mathrm{~h}$. The solid was then collected by vacuum filtration and washed with methanol until washings ran colourless to give a blue solid $(0.72 \mathrm{~g}$, 34\%). ${ }^{1} \mathrm{H}$ NMR (600 MHz, $\left.\mathrm{CDCl}_{3}\right) \delta 8.76(\mathrm{~s}, 2 \mathrm{H}), 7.42(\mathrm{~d}, J=2.5 \mathrm{~Hz}, 2 \mathrm{H}), 7.22(\mathrm{dd}, J=8.7,2.5$ $\mathrm{Hz}, 2 \mathrm{H}), 6.96(\mathrm{~d}, J=8.7 \mathrm{~Hz}, 2 \mathrm{H}), 5.34(\mathrm{t}, J=3.3 \mathrm{~Hz}, 2 \mathrm{H}), 3.97-3.88(\mathrm{~m}, 2 \mathrm{H}), 3.68-3.58(\mathrm{~m}$, 2H), $2.04-1.94(\mathrm{~m}, 4 \mathrm{H}), 1.92-1.82(\mathrm{~m}, 4 \mathrm{H}), 1.73-1.63(\mathrm{~m}, 4 \mathrm{H})$ LRMS (CI+) $m / z 463[\mathrm{MH}]^{+}$ HRMS Found (CI+): $[\mathrm{MH}]^{+} 463.18632, \mathrm{C}_{26} \mathrm{H}_{27} \mathrm{~N}_{2} \mathrm{O}_{6}$ requires 463.18691

\section{2,9-dihydroxy-7,14-di(thiophen-2-yl)diindolo[3,2,1-de:3',2',1'-ij][1,5]naphthyridine-6,13-}

\section{dione}


(E)-5,5'-bis((tetrahydro-2H-pyran-2-yl)oxy)-[2,2'-biindolinylidene]-3,3'-dione $\quad(2.2 \quad \mathrm{~g}, \quad 4.8$ $\mathrm{mmol})$, and 2-(thiophen-2-yl)acetyl chloride $(3.6 \mathrm{~mL}, 29 \mathrm{mmol})$ were dissolved in anhydrous xylene $(96 \mathrm{~mL})$ and the reaction refluxed at $165^{\circ} \mathrm{C}$ for $24 \mathrm{~h}$. The blue reaction turned purple after $1 \mathrm{~h}$. After $24 \mathrm{~h}$ the vapours from the argon flow were no longer acidic. The reaction was transferred to a $250 \mathrm{~mL}$ round bottomed flask washing with methanol and chloroform. All solvent was removed in vacuo to give a black residue. The residue was taken up in methanol and the yellow methanol washings carefully decanted off, to leave the black solid in the flask. After five methanol washings the solid was suspended in methanol and, with stirring, $5 \%$ sodium hydroxide solution (20 mL, 2.5 equiv) was added. The solution immediately turned dark red and then black and allowed to stir for $12 \mathrm{~h}$. $6 \mathrm{M}$ hydrochloric acid $(4.1 \mathrm{~mL}, 24.8 \mathrm{mmol})$ was then added to neutralise the reaction. The methanol and water were then removed in vacuo and the resulting residue was washed with a small amount of water which was carefully decanted off, to remove any salts. The solid was then taken up in acetone and filtered off under reduced pressure. The resulting dark solid was washed with water, acetone then methanol, then air dried to give a black solid ( $0.7 \mathrm{~g}, 29 \%)$. ${ }^{1}$ H NMR (600 MHz, DMSO) $\delta 10.03(\mathrm{~s}, 2 \mathrm{H}), 8.22(\mathrm{~d}, J=8.7 \mathrm{~Hz}, 2 \mathrm{H}), 7.96(\mathrm{~d}, J=4.5 \mathrm{~Hz}, 2 \mathrm{H})$, $7.74(\mathrm{~d}, J=3.6 \mathrm{~Hz}, 2 \mathrm{H}), 7.53(\mathrm{~d}, J=2.4 \mathrm{~Hz}, 2 \mathrm{H}), 7.35(\mathrm{dd}, J=4.5,3.6 \mathrm{~Hz}, 2 \mathrm{H}), 7.07$ (dd, $J=8.7$, $2.4 \mathrm{~Hz}, 2 \mathrm{H}) \mathbf{L R M S}(\mathrm{ES}+) m / z 507[\mathrm{MH}]^{+}$HRMS Found (ES+): [MH] $]^{+}$507.0482, $\mathrm{C}_{28} \mathrm{H}_{15} \mathrm{~N}_{2} \mathrm{O}_{4} \mathrm{~S}_{2}$ requires 507.0473

\section{2,9-bis((2-octyldodecyl)oxy)-7,14-di(thiophen-2-yl)diindolo[3,2,1-de:3',2',1'-}

\section{ij] [1,5]naphthyridine-6,13-dione}

2,9-dihydroxy-7,14-di(thiophen-2-yl)diindolo[3,2,1-de:3',2',1'-ij][1,5]naphthyridine-6,13-dione

$(0.7 \mathrm{~g}, 1.4 \mathrm{mmol})$ potassium carbonate $(2.67 \mathrm{~g}, 19 \mathrm{mmol})$ and 9-(bromomethyl)nonadecane $(1.25$ $\mathrm{g}, 3.5 \mathrm{mmol})$ were dissolved in dimethylformamide $(28 \mathrm{~mL})$ and heated at $60{ }^{\circ} \mathrm{C}$ with stirring for 
$24 \mathrm{~h}$. The reaction was then cooled and poured into a separating funnel containing brine and hexane. The organic layer was extracted with brine $(5 \times 50 \mathrm{~mL})$, separated and filtered under reduced pressure to remove black particulates. The purple organic filtrate was then dried over magnesium sulphate, filtered and concentrated in vacuo to give a purple oil. The crude oil was purified by flash chromatography on silica gel $\left(9: 1\right.$, PET: EtOAc, $\left.R_{F}=0.2\right)$ to give a pure purple oil (119 mg, 8\%). ${ }^{1} \mathbf{H}$ NMR (600 MHz, $\left.\mathrm{CDCl}_{3}\right) \delta 8.40(\mathrm{~d}, J=8.9 \mathrm{~Hz}, 2 \mathrm{H}), 7.74(\mathrm{dd}, J=3.6,0.8$ $\mathrm{Hz}, 2 \mathrm{H}), 7.69(\mathrm{dd}, J=5.1,0.8 \mathrm{~Hz}, 2 \mathrm{H}), 7.65(\mathrm{~d}, J=2.5 \mathrm{~Hz}, 2 \mathrm{H}), 7.27-7.24(\mathrm{~m}, 2 \mathrm{H}), 7.08(\mathrm{dd}, J$ $=8.9,2.5 \mathrm{~Hz}, 2 \mathrm{H}), 3.81(\mathrm{~d}, J=5.8 \mathrm{~Hz}, 4 \mathrm{H}), 1.81-1.73(\mathrm{~m}, 2 \mathrm{H}), 1.47-1.40(\mathrm{~m}, 4 \mathrm{H}), 1.40-1.35$ (m, 4H), $1.35-1.20(\mathrm{~m}, 56 \mathrm{H}), 0.90-0.84(\mathrm{~m}, 12 \mathrm{H}){ }^{13} \mathbf{C} \mathbf{~ N M R}\left(150 \mathrm{MHz}, \mathrm{CDCl}_{3}\right) \delta$ 158.5, 158.0, 138.0, 134.8, 130.3, 130.2, 130.1, 127.1, 126.3, 125.1, 122.5, 118.4, 118.3, 111.0, 71.9, 38.0, 32.0, 31.4, 30.2, 29.8, 29.7, 29.5, 26.9, 22.8, 14.3 LRMS (ES-) $m / z 1065[\mathrm{M}-\mathrm{H}]^{+}$

\section{7,14-bis(5-bromothiophen-2-yl)-2,9-bis((2-octyldodecyl)oxy)diindolo[3,2,1-de:3',2',1'-}

\section{ij][1,5]naphthyridine-6,13-dione}

2,9-bis((2-octyldodecyl)oxy)-7,14-di(thiophen-2-yl)diindolo[3,2,1-de:3',2',1'-

$i j][1,5]$ naphthyridine-6,13-dione (119 mg, $0.11 \mathrm{mmol})$ was dissolved in dichloromethane $(15 \mathrm{~mL})$ and the solution was cooled to $0{ }^{\circ} \mathrm{C}$. N-Bromosuccinimide ( $43 \mathrm{mg}, 0.24 \mathrm{mmol}$ ) was added all at once to the stirring solution and the reaction was covered and kept at $0{ }^{\circ} \mathrm{C}$ for $30 \mathrm{~min}$. The ice bath was then removed and the reaction allowed to warm to room temperature and stir for a further 12 h. After $1 \mathrm{~h}$ the solution had changed from purple to sapphire blue. After $12 \mathrm{~h}$ the reaction was diluted with further dichloromethane and washed with water $(2 \times 30 \mathrm{~mL})$ then brine $(30 \mathrm{~mL})$, dried over magnesium sulphate and concentrated to give a waxy solid. Methanol was added to the flask and to give a suspension, which was then collected by vacuum filtration to give a pure blue waxy solid (60 mg, 44\%) ${ }^{1} \mathbf{H}$ NMR (600 MHz, $\left.\mathrm{CDCl}_{3}\right) \delta 8.34(\mathrm{~d}, J=8.9 \mathrm{~Hz}, 2 \mathrm{H}), 7.67$ (d, $J=2.4 \mathrm{~Hz}$, 
2H), $7.54(\mathrm{~d}, J=3.9 \mathrm{~Hz}, 2 \mathrm{H}), 7.21(\mathrm{~d}, J=3.9 \mathrm{~Hz}, 2 \mathrm{H}), 7.07(\mathrm{dd}, J=8.9,2.4 \mathrm{~Hz}, 2 \mathrm{H}), 3.83(\mathrm{~d}, J=$ $5.7 \mathrm{~Hz}, 4 \mathrm{H}), 1.83-1.75(\mathrm{~m}, 2 \mathrm{H}), 1.48-1.41(\mathrm{~m}, 4 \mathrm{H}), 1.41-1.36(\mathrm{~m}, 4 \mathrm{H}), 1.36-1.17(\mathrm{~m}, 56 \mathrm{H})$ $0.91-0.83(\mathrm{~m}, 12 \mathrm{H}){ }^{13} \mathbf{C}$ NMR $\left(150 \mathrm{MHz}, \mathrm{CDCl}_{3}\right) \delta 158.1,137.6,136.6,123.0,129.2,129.0$, $126.8,124.4,122.4,118.7,111.0,72.0,51.0,38.0,32.0,31.4,30.2,29.8,29.5,27.0,22.8,14.3$

HRMS Found (ES-): [M-H]- 1221.4817, $\mathrm{C}_{68} \mathrm{H}_{91} \mathrm{Br}_{2} \mathrm{~N}_{2} \mathrm{O}_{4} \mathrm{~S}_{2}$ requires 1221.4787

\section{Polymer INDT-T}

7,14-bis(5-bromothiophen-2-yl)-2,9-bis((2-octyldodecyl)oxy)diindolo[3,2,1-de:3',2',1'$i j][1,5]$ naphthyridine-6,13-dione $(60.1 \mathrm{mg}, 49.1 \mu \mathrm{mol})$, tris(dibenzylideneacetone)dipalladium(0) (2.6 mg, $2.8 \mu \mathrm{mol}, 6 \mathrm{~mol} \%$ ), tri(o-tolyl)phosphine $(3.47 \mathrm{mg}, 11.4 \mu \mathrm{mol}$ ) and 2,5bis(trimethylstannyl)thiophene $(20.15 \mathrm{mg}, 49.1 \mu \mathrm{mol})$ were added to a dry $10 \mathrm{~mL}$ microwave vial equipped with a stirrer bar and sealed. Chlorobenzene $(2.5 \mathrm{~mL})$ was added via syringe and the solution degassed with argon for $30 \mathrm{~min}$. The vial was then placed in a microwave reactor and heated as follows: $10 \mathrm{~min}$ at $100{ }^{\circ} \mathrm{C}, 5 \mathrm{~min}$ at $120^{\circ} \mathrm{C}, 5 \mathrm{~min}$ at $140{ }^{\circ} \mathrm{C}, 5 \mathrm{~min}$ at $160{ }^{\circ} \mathrm{C}$ and $20 \mathrm{~min}$ at $180{ }^{\circ} \mathrm{C}$. The vial was then allowed to cool and the reaction had changed colour from sapphire blue to turquoise. The reaction mixture was added dropwise slowly into rapidly stirring methanol $(70 \mathrm{~mL})$ and allowed to stir for $2 \mathrm{~h}$, forming fine dark blue fibres. The polymeric material was then filtered under reduced pressure into a cellulose thimble and washed with methanol then acetone. The polymer was purified by soxhlet extraction as follows: acetone for $12 \mathrm{~h}$, hexane for $12 \mathrm{~h}$ and chloroform for $12 \mathrm{~h}$. The chloroform was then concentrated to give a turquoise plastic-like film on the round bottomed flask. This film was dissolved in a minimum volume of hot chlorobenzene $(\sim 2.5 \mathrm{~mL})$ then added dropwise slowly into rapidly stirring methanol cooled to $0{ }^{\circ} \mathrm{C}$. Once addition was complete the methanol was stirred for 30 min then filtered under vacuum, washing carefully with methanol then a small amount of acetone then allowed to dry, forming a dark blue film. The 
polymer was air dried for $1 \mathrm{~h}$ then placed in a vial and dried under vacuum for $12 \mathrm{~h}(49 \mathrm{mg}, 87 \%)$.

GPC (PS): $\mathrm{Mn}=15687, \mathrm{Mw}=49381, \mathrm{PDI}=3.15 ; \mathbf{U V}(\mathrm{PhCl}) \lambda_{\max } 797$, (Thin film) $\lambda_{\max } 790$

\section{ASSOCIATED CONTENT}

Supporting Information. Experimental details, characterizations and NMR spectra. This material is available free of charge via the Internet at http://pubs.acs.org.

\section{AUTHOR INFORMATION}

\section{Corresponding Author}

*Email: h.bronstein@ucl.ac.uk (H.B.).

\section{Funding Sources}

This material is based upon work supported as part of the Qatar NPRP 7-286-1-046 research grant.

\section{Insert Table of Contents Graphic and Synopsis Here}

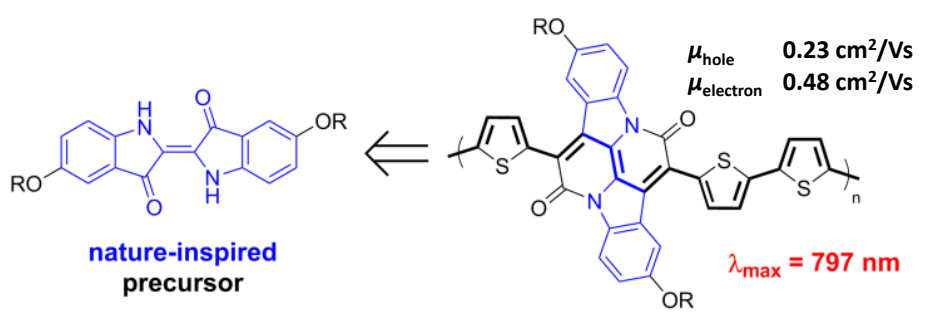

A novel, extremely narrow band-gap polymer with a structure based on natural indigo has been synthesised and exhibits high crystallinity, high ambipolar transport in OFET devices, and OPV device efficiencies up to $2.35 \%$ with light absorbance up to $950 \mathrm{~nm}$, demonstrating potential in near-IR photovoltaics. 


\section{REFERENCES}

1. Bronstein, H.; Chen, Z.; Ashraf, R. S.; Zhang, W.; Du, J.; Durrant, J. R.; Shakya Tuladhar, P.; Song, K.; Watkins, S. E.; Geerts, Y.; Wienk, M. M.; Janssen, R. A. J.; Anthopoulos, T.; Sirringhaus, H.; Heeney, M.; McCulloch, I. J. Am. Chem. Soc. 2011, 133, (10), 3272-3275.

2. Zhang, X.; Bronstein, H.; Kronemeijer, A. J.; Smith, J.; Kim, Y.; Kline, R. J.; Richter, L. J.; Anthopoulos, T. D.; Sirringhaus, H.; Song, K.; Heeney, M.; Zhang, W.; McCulloch, I.; DeLongchamp, D. M. Nat Commun 2013, 4.

3. Guo, X.; Zhou, N.; Lou, S. J.; Smith, J.; Tice, D. B.; Hennek, J. W.; Ortiz, R. P.; Navarrete, J. T. L.; Li, S.; Strzalka, J.; Chen, L. X.; Chang, R. P. H.; Facchetti, A.; Marks, T. J. Nat Photon 2013, 7, (10), 825-833.

4. $\quad$ Li, W.; Hendriks, K. H.; Roelofs, W. S. C.; Kim, Y.; Wienk, M. M.; Janssen, R. A. J. Adv. Mater. 2013, 25, (23), 3182-3186.

5. Naik, M. A.; Patil, S. J. Polym. Sci. A Polym. Chem. 2013, 51, (20), 4241-4260.

6. $\quad$ Deng, P.; Zhang, Q. Polym. Chem. 2014, 5, (10), 3298-3305.

7. Guo, C.; Sun, B.; Quinn, J.; Yan, Z. Q.; Li, Y. N. J. Mater. Chem. C 2014, 2, (21), 42894296.

8. Gorner, H.; Pouliquen, J.; Kossanyi, J. Can. J. Chem.-Rev. Can. Chim. 1987, 65, (4), 708-717.

9. Rondão, R.; Seixas de Melo, J.; Melo, M. J.; Parola, A. J. J. Phys. Chem. A 2012, 116, (11), 2826-2832.

10. Irimia-Vladu, M.; Głowacki, E. D.; Troshin, P. A.; Schwabegger, G.; Leonat, L.;

Susarova, D. K.; Krystal, O.; Ullah, M.; Kanbur, Y.; Bodea, M. A.; Razumov, V. F.; Sitter, H.; Bauer, S.; Sariciftci, N. S. Adv. Mater. 2012, 24, (3), 375-380.

11. Klimovich, I. V.; Leshanskaya, L. I.; Troyanov, S. I.; Anokhin, D. V.; Novikov, D. V.; Piryazev, A. A.; Ivanov, D. A.; Dremova, N. N.; Troshin, P. A. J. Mater. Chem. C 2014.

12. Engi, G. Z. Angew. Chem. 1914, 27, 144.

13. Glowacki, E. D.; Leonat, L.; Voss, G.; Bodea, M.; Bozkurt, Z.; Irimia-Vladu, M.; Bauer, S.; Sariciftci, N. S. In Natural and nature-inspired semiconductors for organic electronics, 2011; 2011; pp 81180M-81180M-10.

14. He, B.; Pun, A. B.; Zherebetskyy, D.; Liu, Y.; Liu, F.; Klivansky, L. M.; McGough, A. M.; Zhang, B. A.; Lo, K.; Russell, T. P.; Wang, L.; Liu, Y. J. Am. Chem. Soc. 2014, 136, (42), 15093-15101.

15. Noriega, R.; Rivnay, J.; Vandewal, K.; Koch, F. P. V.; Stingelin, N.; Smith, P.; Toney, M. F.; Salleo, A. Nat Mater 2013, 12, (11), 1038-1044.

16. Hendriks, K. H.; Li, W.; Wienk, M. M.; Janssen, R. A. J. J. Am. Chem. Soc. 2014, 136, (34), 12130-12136.

17. Bronstein, H.; Collado-Fregoso, E.; Hadipour, A.; Soon, Y. W.; Huang, Z.; Dimitrov, S. D.; Ashraf, R. S.; Rand, B. P.; Watkins, S. E.; Tuladhar, P. S.; Meager, I.; Durrant, J. R.; McCulloch, I. Adv. Funct. Mater. 2013, 23, (45), 5647-5654. 